\title{
Light and Hormone Interactions in the Seed-to-Seedling Transition
}

Katherine M. Warpeha $\mathrm{a}^{\mathrm{a}^{*}}$ and Beronda L. Montgomery ${ }^{\mathrm{b}, \mathrm{c}}$

${ }^{a}$ Molecular, Cell and Developmental Program, Department of Biological Sciences, University of Illinois at Chicago, $900 \mathrm{~S}$ Ashland Ave, m/c 567, Chicago, IL, 60607

${ }^{\mathrm{b}}$ Department of Energy - Plant Research Laboratory, Michigan State University, 612 Wilson Road, East Lansing, MI, 48823

${ }^{\mathrm{c}}$ Department of Biochemistry and Molecular Biology, Michigan State University, 612 Wilson Road, East Lansing, MI, 48823

* Correspondence to:

Katherine M. Warpeha, Molecular, Cell and Developmental Program, Department of Biological

Sciences, University of Illinois at Chicago, Chicago, IL, Phone 312-996-7646, e-mail:

kwarpeha@uic.edu

(C) 2015. This manuscript version is made available under the Elsevier user license http://www.elsevier.com/open-access/userlicense/1.0/ 


\begin{abstract}
Plants exhibit sensitivity to dynamic or changing environments and respond to such fluctuations through short- and long-term adaptive responses. The transition from seed to established seedling is a critical phase of the plant life cycle. This brief, but highly important, phase is linked to species persistence and impacts long-term population dynamics. During the seed-to-seedling transition, key factors that modulate plant form and function are light, hormones, and integrated signaling at the light-hormone interface. During this stage of early plant development, germination, seedling development and the critical heterotrophic-to-autotrophic conversion, the latter of which includes chloroplast development and differentiation, are modulated by external light parameters and homeostasis of several plant hormones. Specific mechanisms used to mediate responses to light and/or hormones during the seed-to-seedling transition include the regulation of gene expression, protein dynamics, and metabolites (including sugars and reactive oxygen species). In this review, we highlight key mechanistic factors and components that are especially linked to integrating responses to light and hormones during germination and the postgerminative seed-to-seedling transition. These light-/hormone-dependent mechanisms have implications for short- and long-term dynamics and diversity of natural plant species and communities.
\end{abstract}

Keywords: heterotrophic-to-autotrophic conversion; hormones; light; photoreceptors; seed-toseedling; seedling; signaling; cotyledon 


\section{Introduction}

The seed-to-seedling transition is a critical stage of plant development. This transition has been described as a 'bottleneck' for species establishment that can ultimately drive the composition of plant populations (Poorter, 2007). This brief but profound transition from seed to established seedling is associated with the dynamics and/or diversity of natural communities and maintaining species diversity and persistence in natural environments (Muscarella et al., 2013). The seed-to-seedling transition comprises a transition from heterotrophic growth to autotrophic growth, characterized by organ development and maturation of the chloroplasts with the onset of photosynthesis, to promote the new life cycle of the plant. This process is regulated by light cues perceived by photoreceptors, hormone-mediated signaling and available nutrients. Newly germinated seedlings are capable of responding to short-term dynamic environmental conditions, including daily cycles of dark and light cues, fluctuating light conditions, other environmental oscillations, and long-term changes in natural environments, including climate change. Such adaptive responses are critical for these organisms to optimize growth, reproduction and survival. Responses to abiotic and biotic signals can include both short-term and long-term adaptations. Short-term responses can include activation of signaling pathways or stress responses; longerterm adaptations can include acclimatory physiological changes and survival strategies including colonization and competition advantages.

The focus of this review is on the interaction of light and hormone signaling pathways and responses in the seed-to-seedling transition and early seedling development, including the heterotrophic-to-autotrophic transition. We will address the role of photoreceptor- and hormonedependent regulation of gene expression, protein homeostasis, plastid 
differentiation/development, and associated impacts on facilitating the seed-to-seedling transition and seedling establishment, tuned to external cues. Such responses are critical for plants to adapt to dynamic environments and changing environmental cues in natural contexts, including those due to longer-term alterations. This latter association with long-term alterations may result in an expansion of the limitations of particular genotypes, or be evidence of links between phenotypic plasticity and evolutionary adaptation (Forsman, 2014).

1.1 Tuning gene expression during the seed-to-seedling transition. Tuning of the expression of many plant genes occurs in responses to light or hormone cues. Specific wavelengths of light or distinct hormones can modulate the expression of a significant portion of the plant genome $-20 \%$ or more of the plant genome has been estimated to be regulated by white light (Jiao et al., 2005); similar proportions of the genome (up to 15\%) may respond to various hormones (Nemhauser et al., 2006). Primary metabolism, which is supported by the reserves of the seed and upon seedling emergence is regulated by light (Farré and Weise, 2012), is also very important to a successful transition to seedling.

1.2. Light and the seed-to-seedling transition. The seed-to-seedling transition is characterized by the light-dependent etioplast-to-chloroplast transition and the onset of photosynthesis. Light is critical for establishing developmental and metabolic changes during this period, including seed germination, hypocotyl elongation, cotyledon and true leaf development, plastid development and greening, among others (Franklin and Quail, 2010; Kami et al., 2010). Distinct wavelengths of light are detected by multiple plant photoreceptors including the red/far-red responsive phytochromes (phy), blue/ultraviolet-A absorbing cryptochromes (cry) and phototropins (PHOT), and ultraviolet-B absorbing photoreceptors such as UVR8 (Franklin and Quail, 2010; Rizzini et al., 2011) [see Table 1]. However, known 
photoreceptors cannot explain all light-dependent phenotypes, for example some responses to UV-B (Biever et al. 2014), UV or blue light (Warpeha et al., 2008), or green wavelengths (Zhang et al., 2011; reviewed in Wang and Folta, 2013).

Phytochromes regulate light-dependent seed germination (Arana et al., 2014; Botto et al., 1995; Botto et al., 1996; Hennig et al., 2002; Heschel et al., 2008; Heschel et al., 2007; Shinomura et al., 1994) and de-etiolation (Dehesh et al., 1993; Franklin et al., 2003; Hennig et al., 2001; Johnson et al., 1994; Monte et al., 2003; Nagatani et al., 1993; Parks and Quail, 1993; Parks and Spalding, 1999; Reed et al., 1994). Cryptochromes also contribute to the regulation of de-etiolation, primarily in response to blue light (Ahmad et al., 1998; Ahmad et al., 1995; Folta and Spalding, 2001). Blue-light receptive phototropins primarily drive directional growth of seedlings or phototropism (Folta and Spalding, 2001; Sakai et al., 2001). UV-B photoreceptors, including UVR8, contribute to phototropism and photomorphogenesis (Favory et al., 2009; Huang et al., 2014; Rizzini et al., 2011; Vandenbussche et al., 2014).

1.3. Hormones and the seed-to-seedling transition. Hormones are also critical for proper seed-to-seedling transition and may have both developmental roles and roles in the induction of protective responses against stresses (Kucera et al., 2005; Miransari and Smith, 2014). Specific hormones that play critical roles in this transition include abscisic acid (ABA), gibberellins (GAs), auxins (e.g., indole-3-acetic acid; IAA), ethylene, cytokinins and brassinosteroids (BR) [see Table 2]. ABA accumulates in seeds to promote dormancy and prevent premature germination (reviewed by Cutler et al., 2010; Sakata et al., 2014); whereas GA inhibits dormancy and promotes germination (Gupta and Chakrabarty, 2013; Peter and Stephen, 2012). The role of GA in these processes occurs in part through active antagonism of ABA activity (Cutler et al., 2010). Additionally, GAs function to promote the elongation of 
stems and expansion of leaves (Gupta and Chakrabarty, 2013; Peter and Stephen, 2012). Auxins, the most common of which is IAA, promote cellular elongation and root initiation during seedling establishment (reviewed by Zhao, 2010), and phototropism (reviewed by Hohm et al., 2013). Ethylene promotes the release of dormancy and germination, in part through counteracting the effects of ABA on seeds similarly to GA (Corbineau et al., 2014; Kucera et al., 2005); ethylene also promotes growth and differentiation of shoots and roots in young seedlings (Corbineau et al., 2014). Cytokinins have a role in embryo development via the promotion of cell division and these molecules also promote root elongation (Perilli et al., 2010). The impact of cytokinins can be antagonistic to auxins for many responses (Kieber and Schaller, 2014; Schaller et al., 2015). BRs promote seed germination and seedling elongation (Clouse, 2011). It is clear, based on the antagonism by some hormones on the impact of others, that signals of the multiple hormone pathways can be integrated to impact apposite seed germination and seedling development.

\subsection{Light and hormone interactions and the seed-to-seedling transition. Given some}

of the similar impacts of light and hormones on seedling establishment and development, it is not surprising that multiple plant hormone signaling pathways interface with or are modulated by light signaling pathways during the seed-to-seedling transition. The interaction of light and hormones specifically during de-etiolation has been previously reviewed (Alabadi and Blazquez, 2009; Arsovski et al., 2012; Halliday et al., 2009; Lau and Deng, 2010; Lin and Tang, 2014; Seo et al., 2009; Symons and Reid, 2003). Here, we highlight some examples of interactions between light and hormone signaling closely linked to the seed-to-seedling transition.

Interactions between the GA pathway and phytochromes that primarily impact the stages of seed germination and shoot growth have been established, including phytochrome-dependent 
changes in GA metabolism and GA responsiveness and coordinated regulation of transcription factors (Achard et al., 2007; Arana et al., 2014; de Lucas et al., 2008; Feng et al., 2008; Kurepin et al., 2012; Oh et al., 2007; Oh et al., 2006; Toyomasu et al., 1998). Connections of cryptochrome 1 (cry1) to GA homeostasis and the regulation of hypocotyl growth have also been described (Folta et al., 2003; Zhao et al., 2007), as have cry1 connections to cytokinin signaling during the promotion of photomorphogenesis (Vandenbussche et al., 2007) and the regulation of auxin responsiveness (Folta et al., 2003). Blue-light-induced phototropic curvature of the shoot is mediated by the lateral transport of auxin (reviewed by Briggs, 2014), clearly an important process in the seed-to-seedling transition, when orientation to light is critical. Numerous interactions between phytochromes and auxin signaling during early development have been identified, including the light-dependent promotion of auxin homeostasis (Behringer and Davies, 1992; Behringer et al., 1992; Kurepin et al., 2012; Wu et al., 2010). IAA is transported from the developing leaves to the roots in a light-dependent manner in the early seedling stage, where IAA is required for lateral root formation (Bhalerao et al., 2002). Both phytochromes (Salisbury et al., 2007) and cryptochromes (Zeng et al., 2010) regulate auxin transport that impacts root development in early development. Additionally, PHOT impacts lateral root elongation through impacting auxin-related signal transduction (Moni et al., 2015). A regulation of ABA metabolism by phytochromes and phytochrome-dependent control of ABA-GA interactions that impact ABA- and/or GA-associated germination occurs (Sawada et al., 2008; Seo et al., 2006). Additionally, an interaction between phytochromes and ABA signaling that regulates transcription and impacts germination has been established (Joseph et al., 2014), and transcriptional repression that regulates light-, GA-, and ABA-responsive genes (Hsieh et al., 2012). BR and light antagonistically regulate de-etiolation (Luo et al., 2010). Also, distinct 
interactions between light perception by phytochromes and modulation of BR homeostasis and signaling impact seedling development (Neff et al., 1999; Turk et al., 2003; Turk et al., 2005). Recently, an integration of GA, BR, and phytochrome pathways that is associated with coordinating growth through transcriptional regulation in response to light and hormone signals also was described (Bai et al., 2012).

In addition to visible and far-red light, UV wavelengths also interface with hormone responses. For example, UV-B photoreceptor UVR8 inhibits auxin biosynthesis and promotes GA catabolism, thereby inhibiting hypocotyl elongation (Hayes et al., 2014). UVR8-associated regulation of phototropic bending is correlated with a repression of auxin-responsive genes, indicating additional connections between UV-B and auxin signaling pathways (Vandenbussche et al., 2014).

1.5. Stress, hormones and the seed-to-seedling transition. During the seed-to-seedling transition, seedlings are especially sensitive to biotic and abiotic stresses. Seedlings are highly sensitive to potential photodamage/phototoxicity, primarily associated with excess light absorption (e.g., Barber and Andersson, 1992) resulting in the generation of potentially damaging reactive oxygen species (ROS) (Aarti et al., 2007; Alboresi et al., 2011; Durrant et al., 1990; Krieger-Liszkay, 2005). Accordingly, the induction of protective responses to mitigate potential light stress occurs during the seed-to-seedling transition and impacts seedling establishment (for review see Corbineau et al., 2014; El-Maarouf-Bouteau and Bailly, 2008). However, ROS may also serve as signaling molecules in seedlings. For example, the accumulation of ROS has been associated with breaking seed dormancy and promoting seed germination in Arabidopsis (Leymarie et al., 2011). ROS-associated promotion of germination and seedling development is linked to phytochromes (Chen et al., 2013; Lariguet et al., 2013) 
and light signaling pathways (Busch and Montgomery, 2015). ROS also are associated with several hormones in impacting germination and seedling development. For example, ROS levels are increased by GA and repressed by ABA in the regulation of germination (Lariguet et al., 2013). ROS accumulation is also increased in the presence of ethylene (Corbineau et al., 2014; El-Maarouf-Bouteau et al., 2015). ROS are both induced by treatment with IAA (Joo et al., 2001; Joo et al., 2005; Peer et al., 2013; Schopfer, 2001; Schopfer and Liszkay, 2006) and serve as a signal for auxin-mediated responses, including elongation growth (Liszkay et al., 2004; Schopfer, 2001; Schopfer and Liszkay, 2006) and gravitropism (Joo et al., 2001; Joo et al., 2005).

\subsection{Responses to environmental cues during the seed-to-seedling transition and}

adaptation. Light cues perceived by photoreceptors and transduced via hormone-mediated signaling are essential for successful seedling establishment in natural contexts (Borevitz et al., 2002; Chen et al., 2008). Distinct Arabidopsis accessions have distinct quantitative trait loci (QTL) and expression level polymorphisms (ELPs) that underlie natural variations in light and hormone responses during seedling establishment (Borevitz et al., 2002; Delker et al., 2010; Yanovsky et al., 1997). Some of the natural variation related to light responses has been linked to photoreceptor variants naturally found in the environment (Botto et al., 2003; Maloof et al., 2001). Recently, an allele of a QTL for local adaptation of the timing of seed germination linked to ABA signaling has been described (Amiguet-Vercher et al., 2015). Such variation has been implicated in long-term plant adaptation responses in nature and in driving natural population diversity, range extension, and population dynamics (Alonso-Blanco et al., 2009; Delker and Quint, 2011; Mitchell-Olds, 2001; Remington and Purugganan, 2003; Weigel, 2012). 


\section{Mechanisms of the integration of light and hormone signaling in the seed-to-seedling}

transition

Mechanisms for integrating light and hormone signaling during the transition from seed to established seedling include regulation of some common factors. In cases where light and a specific hormone result in the same physiological responses, these signals can impinge upon a single factor or initiate a transcriptional cascade. Alternatively, light and hormones can have antagonistic effects on a single factor, thereby integrating divergent responses of these distinct cues.

Specific factors mediate the integration of light and hormone signaling during the seedto-seedling transition, including a transcriptional regulator Imbibition-inducible 1 (IMB1) (Duque and Chua, 2003) and C2H2-type ZINC FINGER PROTEIN3 (ZFP3) (Joseph et al., 2014). Both IMB1 and ZFP3 have been shown to impact both ABA and phytochrome-dependent signaling linked to germination. Both phytochrome B (phyB) and cry1 activities also have been specifically associated with regulation of auxin efflux transporter ATP-BINDING CASSETTE B19 (ABCB19) that mediates auxin transport-associated regulation of hypocotyl growth (Wu et al., 2010). Additionally, PHOT1 directly interacts with ABCB19 to regulate phototropism (Christie et al., 2011). A GATA transcription factor, i.e., GATA2, functions in crosstalk between BR and light (Luo et al., 2010). Additional factors functioning in response to light and hormones include members of the Nuclear Factor Y (NF-Y) family, particularly the LEAFY COTYLEDON 1 (LEC1) and LEC1-LIKE members. LEC1 and LEC1-LIKE interact with ABAresponse elements in seed-specific genes to impact embryogenesis and seed maturation (Yamamoto et al., 2009); however, these factors also regulate etiolation responses in seedlings, in part as integrators of light and hormone signaling during embryogenesis and post-germination 
etiolation (Junker et al., 2012). LEC1 was also implicated in integrating responses to blue light and ABA (Warpeha et al., 2007), and ABA previously (Lapik and Kaufman, 2003), resulting from interaction with the protein Pirin1 (PRN1), a transcriptional cofactor protein. PRN1 also has been associated with responses to UV (Orozco-Nunnelly et al., 2014b) and biotic stress (Warpeha et al., 2013).

PRN1 is also associated with abiotic stress, including drought (Catala et al., 2007) and abiotic signaling, particularly white light- and UV-controlled orientation and growth (OrozcoNunnelly et al., 2014b). The recent observation that multiple copies of hormone-regulated, abiotic-stress-associated, and light-responsive motifs are present in the $P R N 1$ promoter suggests that the PRN1 protein may also function in the integration of hormone and light responses (Orozco-Nunnelly et al., 2014a). PRN1 regulates quercetin levels in the young seedling, and the effects on quercetin are light dependent in the seed-to-seedling transition (Orozco-Nunnelly et al., 2014b). Quercetin is a flavonoid derived from phenylalanine, a potent antioxidant (Agati and Tattini, 2010) and UV-screening molecule (Rozema et al., 2002). Quercetin synthesis, like many flavonoids, is induced by light, most efficiently by UV and B (Kubasek et al., 1992), and accumulates in the cotyledonary node, hypocotyl/root transition and the elongation zone of the root in young Arabidopsis seedlings (Peer et al., 2001). In vivo evidence indicates that flavonols regulate auxin accumulation; studies of transparent testa $4(t t 4)$ mutant, which makes no flavonols, including kaempferol and quercetin, support a role for flavonoids in regulating auxin transport during seedling development (Brown et al., 2001; Buer and Muday, 2004; Murphy et al., 2000). Changes in light-induced auxin responses or metabolism may explain the overall PRN1-quercetin-caused seedling responses in light (Orozco-Nunnelly et al., 2014b) in the seedto-seedling transition, as correct auxin transport is required for orientation and hypocotyl 
elongation in light-grown, but not dark-grown seedlings (Jensen et al., 1998). Flavonols also induce changes in auxin transport, as demonstrated in roll-2 (repressor of lrx 1 ) mutant seedlings (Kuhn et al., 2011). When auxin transport was compared in flavonoid-deficient $t t 4$ and quercetindeficient $t t 7$ (makes kaempferol but not quercetin) mutants, data indicated that derivatives of quercetin can inhibit basipetal auxin transport, elongation, and gravitropism (Lewis et al., 2011).

In this window of early seedling development, it is clear that photoreceptors have major regulatory, growth and development roles via interactions with hormone signaling pathways or hormone-mediated changes in metabolism or transport. These impacts affect germination and post-germinative processes in various tissues and temporal patterns. Ultimately, these light- and hormone-regulated processes influence the overall architecture and size of the seedling.

\section{Regulation of gene expression}

The role of modifications of gene expression, including transcription factor-mediated regulation of gene expression and chromatin remodeling or epigenetic modifications, in regulating the seed-to-seedling transition are recognized (Bouyer et al., 2011; Jia et al., 2014; van Zanten et al., 2014). Transcription factors bind promoter and/or enhancer segments of DNA to impact expression of genes (Phillips and Hoopes, 2008). A detailed list and mechanisms of transcriptional regulators known to function in light signaling and/or hormone signaling extend beyond the scope of this current review. Here, we specifically highlight gene expressionassociated factors linked to integrated responses to light and hormones during the seed-toseedling transition.

Histone deacetylases (HDACs) result in tighter wrapping of DNA on histones that represses gene expression (Jaenisch and Bird, 2003; Li et al., 2007). DNA methylases can 
activate or repress gene transcription through histone methylation (Li et al., 2007), and other factors can impart epigenetic control over gene expression. There is both active repression of seedling development during the seed development and maturation stage (Jia et al., 2014; van Zanten et al., 2014), and the repression of seed maturation during the vegetative or seedling development stage (Jia et al., 2014). The role of epigenetic control in this process can involve, or be independent of, the roles of hormones ABA and GA (Bouyer et al., 2011; van Zanten et al., 2014). Furthermore, a role for histone deacetylation in inhibiting germination and coordinating the timing of the expression of some photosynthesis genes during the seed-to-seedling transition has been observed (van Zanten et al., 2014). Red light illumination acting through PhyB has been shown to promote seed germination through epigenetic transcriptional activation of genes encoding GA biosynthetic enzymes involving a histone demethylation process (Cho et al., 2012). Thus, light signaling, hormone signaling, and the interactions of light and hormone signals impact the seed-to-seedling transition through processes associated directly with the regulation of gene expression.

\section{Regulation of protein abundance/turnover during the seed-to-seedling transition}

Regulated protein degradation is implicated as a key factor in coordinating the seed-toseedling transition. For example, the ubiquitin ligases, which ubiquitinate protein targets and thereby mark them for turnover, have been shown to impact this transition (Stone et al., 2006; Zhang et al., 2005). The KEEP ON GOING (KEG) E3 ligase has been associated with ABAdependent regulation of germination and early seedling development (Stone et al., 2006). ABI3interacting protein (AIP2) is responsible for targeting E3 ligase regulator ABI3 for degradation, which is associated with regulation of germination responses and vegetative seedling 
development (Zhang et al., 2005). Specific components of the $\mathrm{N}$-end rule pathway that is associated with targeting proteins for degradation also are associated with regulation of the seedto-seedling transition, specifically ABA-dependent seed germination and seedling development (Holman et al., 2009).

Phytochromes and cryptochromes regulate protein turnover through impacting COP1, which is a RING-finger E3 ligase that negatively regulates photomorphogenesis (Liu et al., 2011; Sheerin et al., 2015; Zuo et al., 2011). Specifically, phytochromes and cryptochromes interact with SPA (SUPPRESSOR OF PHYA-105) proteins, which physically interact with COP1 and increase its E3 ligase function (Lian et al., 2011; Liu et al., 2011; Saijo et al., 2003; Seo et al., 2003; Sheerin et al., 2015; Zuo et al., 2011). Nuclear-localized phytochromes interact with PHYTOCHROME-INTERACTING FACTORS (PIFs), which also negatively regulate photomorphogenesis (de Lucas and Prat, 2014; Leivar and Quail, 2011). Interactions of PIFs with light-activated phytochromes result in targeting of the PIFs for degradation by the $26 \mathrm{~S}$ proteasome (de Lucas and Prat, 2014). Notably, PIFs have been implicated in multiple studies in GA, BR, and auxin signaling; thus, these factors impact protein turnover and serve as integrators of light and hormone signaling [reviewed by (de Lucas and Prat, 2014)]. Light also regulates protein abundance in the plastids through light-regulated control of plastid translation (MarínNavarro et al., 2007), a critical part of chloroplast development and function during seedling establishment.

\section{Metabolism and the heterotrophic-to-autotrophic growth transition}

During the transition of heterotrophic growth to photosynthesis-supported autotrophy, seed storage reserves are mobilized to provide energy to support growth and development during 
seedling establishment. Seed reserves support light- and circadian-regulated primary metabolism to fuel the successful transition to seedling (Farré and Weise, 2012). Environmental and circadian regulation impact the source to sink relationships that are developing during the transition, with coordination of growth strongly altered by carbon availability in the form of sugars (Stitt and Zeeman, 2012). Like light, hormones also impact metabolism, particularly sugar metabolism, in the seed-to-seedling transition (Dekkers et al., 2008; Song et al., 2012; Yuan and Wysocka-Diller, 2006; Zhu et al., 2009). Sugars participate in hormone activity, but also may serve as signaling entities [reviewed in (Eveland and Jackson, 2012)]. Sugar impacts on the seedto-seedling transition and subsequent development in seedlings also depend on the availability of other nutrients, including essential nutrients like phosphate, sulfate and nitrogen [reviewed in (Rolland et al., 2006)].

Several specific factors impacting the heterotrophic-to-autotrophic transition have been identified. The plastid triose phosphate isomerase (TPI) has been shown to have a critical role in the transition to autotrophic growth through impacting lipid metabolism (Chen and Thelen, 2010). A triacylglycerollipase also impacts oil breakdown during this transition (Eastmond, 2006).

Levels of the amino acid phenylalanine directly affect plant growth and development (Sullivan et al., 2014). Phenylalanine levels appear critical to proper chloroplast development and stress survival (Warpeha et al., 2008), in addition to proper responses to blue light (Warpeha et al., 2006) and UV responses in the seed-to-seedling transition. Its importance is underscored by the impact of B and UV in particular on the synthesis of flavonoids, a class of phenylpropanoids. Phenylalanine-derived molecules, including flavonoids (Agati and Tattini, 2010) and the simple phenolics (hydroxycinnamic acids and cinnamate esters, etc) (Burchard et 
al., 2000; Landry et al., 1995; Sheahan, 1996) absorb in UV wavelengths, and many of these compounds are found in seeds (Lepiniec et al., 2006). Light induces flavonoid-biosynthetic enzymes sequentially in the temporal order of the biosynthetic pathway and in accordance to the developmental timing of germination and the seed-to-seedling transition, where maximal synthetic capacity peaks in 3-d-old seedlings grown in Wc (Kubasek et al., 1992). The germination process and responses to light within hours to days of germination require a reconfiguration of primary metabolites and secondary metabolism, involving many types of light-responsive metabolites in addition to flavonoids, described in a very detailed review (Chacón et al., 2013). Evolutionary studies in green plant lineages may further understanding of the importance of phenylpropanoids in the seed to seedling transition (Tohge et al., 2013).

The phenylpropanoids, alkaloids and terpenoids are capable of producing thousands of structures within a given genotype, and we are only beginning to uncover how discrete stimuli and changes in environmental stimuli received by the new seedling can enable a different outcome in individual chemical pathways due to the sensitivity to ecosystem parameters, including abiotic and biotic stimuli that impact the seed to seedling transition.

\section{Light-dependent plastid development and heterotrophic-to-autotrophic conversion}

A critical part of the transition to autotrophic growth is the establishment of functional chloroplasts. This establishment depends upon stoichiometric expression of plastid proteins encoded by both nuclear and plastid genome-located genes. Light has been long known to have a critical role in coordinating this process (Pogson and Albrecht, 2011). The involvement and general importance of photoreceptors in this process, including both phytochromes and cryptochromes, also has been described (Chun et al., 2001; Thum et al., 2001; Wellburn and 
Wellburn, 1973), and in some plant species, specific contributions of blue and red light have been quantified (eg. in Cucumis, Hogewoning et al., 2010). Development of plastids in both embryonic development and post-germination is still poorly understood, but involve many transcriptional and translation mechanisms, including plastid-specific elongation factor $G$ (SCO1), required for embryonic survival and seedling plastid development and subsequent survival (Ruppel and Hangarter, 2007).

A limited number of factors that function downstream of the photoreceptors have been identified. These factors include PIFs, i.e., PIF1 and PIF3, which act as transcriptional regulators of light-dependent chloroplast development (Monte et al., 2004; Moon et al., 2008). Recently specific transcription factors, including nuclear-encoded, plastid-targeted sigma factors (SIG) and other known plastid development regulators such as golden-like kinases (GLK1 and GLK2), were shown to function downstream of phytochromes and cryptochromes (Mellenthin et al., 2014; Oh and Montgomery, 2013; Oh and Montgomery, 2014; Oh et al., 2013; Onda et al., 2008). Photoreceptor-dependent regulation of these factors is likely critical for directly regulating stoichiometric expression of nuclear and plastid-encoded components of key photosynthetic and other plastid protein complexes. Such coordination is required for lightdependent development of chloroplasts during seedling development and needed for proper autotrophic growth. SIG2 has a role in light-dependent cotyledon, root and hypocotyl development (Oh and Montgomery, 2013). In Arabidopsis, the redifferentiation of eoplasts, i.e., degenerate plastids present in mature seeds, and the chloroplast greening process are still poorly understood, but involve the protein SEEDLING PLASTID DEVELOPMENT 1 (SPD1) (Ruppel et al., 2011). A number of these above-described factors also directly impact other aspects of 
seedling establishment, where there is still much to investigate regarding the development of fully functioning chloroplasts from dormant seed.

Light-dependent flavonoids localize to chloroplasts in a range of plants (Saunders and McClure, 1976). Phenylpropanoid production in the young seedling includes flavonoids in chloroplasts, where they may act as scavengers of the ROS created in the photosynthetic process (reviewed in Agati et al. 2012). Localization of PRN1, which cleaves the UV-induced flavonoid quercetin, includes the developing plastid in young seedlings (Orozco-Nunnelly et al., 2014b). Thus, flavonoids might have an important function in the protection of the developing plastid from solar UV (Orozco-Nunnelly et al., 2014b).

Chloroplast development during seedling establishment is also impacted by factors associated with hormone signaling. Cytokinins have been shown to stimulate expression of photosynthesis-related genes (Binns, 1994; Kravtsov et al., 2011; Schmülling et al., 1997) and chloroplast development (Chory et al., 1994). Conversely, BRs were shown to inhibit chloroplast development (Li and Chory, 1999; Nagata et al., 2000; Nakano et al., 2001). ABA impacts expression of nuclear photosynthesis-related genes (Kusnetsov et al., 1998; Staneloni et al., 2008) and chloroplast genes (Yamburenko et al., 2013) in developing seedlings.

\section{Conclusions}

Light and hormone signaling control distinct aspects of early plant development, especially the critical phase of seed-to-seedling transition. This transitory, but highly important, phase of the life cycle includes a transition from heterotrophic to autotrophic growth characterized by key changes in organ development and chloroplast development. Light and hormones perceived by receptors to initiate signal transduction affect the timing and pattern of 
seedling emergence, establishment, and development, and tune these to the external environment. While primary metabolites serve to support the embryo transforming into an independent seedling, the young seedling is left vulnerable to the ecology (predators, abiotic

stimuli, etc.) of the environment in which it finds itself. The store of secondary metabolites, thus, serves to mitigate potential damage. Blue and UV in particular rapidly induce the production of phenylpropanoids, which serve in chemical defense and can be deployed in physical defensive structures. Such optimization or fine-tuning of the plants' developmental plasticity and defense mechanisms promotes survival and reproduction over short time scales, and adaptation and influences on plant diversity and population dynamics over longer time scales. In these contexts, understanding this important survival change is vital in the current concerns about accelerated global change.

\section{Acknowledgements}

Work in the Warpeha lab has been funded by NSF MCB National Science Foundation grant MCB-0848113 to KMW and Lon Kaufman, and Illinois Soybean Association funding to KMW. Work in the Montgomery laboratory is funded by the U.S. Department of Energy (Chemical Sciences, Geosciences and Biosciences Division, Office of Basic Energy Sciences, Office of Science, grant no. DE-FG02-91ER20021 to BLM). 


\section{References}

Aarti, D., Tanaka, R., Ito, H., Tanaka, A., 2007. High light inhibits chlorophyll biosynthesis at the level of 5-aminolevulinate synthesis during de-etiolation in cucumber (Cucumis sativus) cotyledons. Photochem Photobiol 83, 171-176.

Achard, P., Liao, L., Jiang, C., Desnos, T., Bartlett, J., Fu, X., Harberd, N.P., 2007. DELLAs contribute to plant photomorphogenesis. Plant Physiol 143, 1163-1172.

Agati, G., Azzarello, E., Pollastri, S., Tattini, M., 2012. Flavonoids as antioxidants in plants: location and functional significance. Plant Sci. 196, 67-76.

Agati, G., Tattini, M., 2010. Multiple functional roles of flavonoids in photoprotection. New Phytol 186, 786-793.

Ahmad, M., Jarillo, J.A., Smirnova, O., Cashmore, A.R., 1998. Cryptochrome blue-light photoreceptors of Arabidopsis implicated in phototropism. Nature 392, 720-723.

Ahmad, M., Lin, C., Cashmore, A.R., 1995. Mutations throughout an Arabidopsis blue-light photoreceptor impair blue-light-responsive anthocyanin accumulation and inhibition of hypocotyl elongation. Plant J 8, 653-658.

Alabadi, D., Blazquez, M.A., 2009. Molecular interactions between light and hormone signaling to control plant growth. Plant Mol Biol 69, 409-417.

Alboresi, A., Dall'Osto, L., Aprile, A., Carillo, P., Roncaglia, E., Cattivelli, L., Bassi, R., 2011. Reactive oxygen species and transcript analysis upon excess light treatment in wild-type 
Arabidopsis thaliana vs a photosensitive mutant lacking zeaxanthin and lutein. BMC Plant Biol 11,62 .

Albrecht, V., Ingenfeld, A., Apel, K., 2006. Characterization of the snowy cotyledon 1 mutant of Arabidopsis thaliana: the impact of chloroplast elongation factor $\mathrm{G}$ on chloroplast development and plant vitality. Plant Mol Biol 60, 507-518.

Albrecht, V., Ingenfeld, A., Apel, K., 2008. Snowy cotyledon 2: the identification of a zinc finger domain protein essential for chloroplast development in cotyledons but not in true leaves. Plant Mol Biol 66, 599-608.

Albrecht, V., Šimková, K., Carrie, C., Delannoy, E., Giraud, E., Whelan, J., Small, I.D., Apel, K., Badger, M.R., Pogson, B.J., 2010. The cytoskeleton and the peroxisomal-targeted SNOWY COTYLEDON3 protein are required for chloroplast development in Arabidopsis. Plant Cell 22, 3423-3438.

Alonso-Blanco, C., Aarts, M.G., Bentsink, L., Keurentjes, J.J., Reymond, M., Vreugdenhil, D., Koornneef, M., 2009. What has natural variation taught us about plant development, physiology, and adaptation? Plant Cell 21, 1877-1896.

Amiguet-Vercher, A., Santuari, L., Gonzalez-Guzman, M., Depuydt, S., Rodriguez, P.L., Hardtke, C.S., 2015. The IBO germination quantitative trait locus encodes a phosphatase 2Crelated variant with a nonsynonymous amino acid change that interferes with abscisic acid signaling. New Phytol 205, 1076-1082. 
Arana, M.V., Sánchez-Lamas, M., Strasser, B., Ibarra, S.E., Cerdán, P.D., Botto, J.F., Sánchez, R.A., 2014. Functional diversity of phytochrome family in the control of light and gibberellinmediated germination in Arabidopsis. Plant Cell Environ 37, 2014-2023.

Arsovski, A.A., Galstyan, A., Guseman, J.M., Nemhauser, J.L., 2012. Photomorphogenesis. Arabidopsis Book 10, e0147.

Bai, M.Y., Shang, J.X., Oh, E., Fan, M., Bai, Y., Zentella, R., Sun, T.P., Wang, Z.Y., 2012. Brassinosteroid, gibberellin and phytochrome impinge on a common transcription module in Arabidopsis. Nat Cell Biol 14, 810-817.

Barber, J., Andersson, B., 1992. Too much of a good thing: light can be bad for photosynthesis. Trends Biochem Sci 17, 61-66.

Behringer, F., Davies, P., 1992. Indole-3-acetic acid levels after phytochrome-mediated changes in the stem elongation rate of dark- and light-grown Pisum seedlings. Planta 188, 85-92.

Behringer, F.J., Davies, P.J., Reid, J.B., 1992. Phytochrome regulation of stem growth and indole-3-acetic acid leves in the $l v$ and $L v$ genotypes of Pisum. Photochem Photobiol 56, 677684.

Bhalerao, R.P., Eklöf, J., Ljung, K., Marchant, A., Bennett, M., Sandberg, G., 2002. Shootderived auxin is essential for early lateral root emergence in Arabidopsis seedlings. Plant J 29, $325-332$. 
Biever, J.J., Brinkman, D., Gardner G., 2014. UV-B inhibition of hypocotyl growth in etiolated Arabidopsis thaliana seedlings is a consequence of cell cycle arrest initiated by photodimer accumulation. J Exp Bot 65, 2949-2961.

Binns, A.N., 1994. Cytokinin accumulation and action: biochemical, genetic, and molecular approaches. Ann Rev Plant Biol 45, 173-196.

Borevitz, J.O., Maloof, J.N., Lutes, J., Dabi, T., Redfern, J.L., Trainer, G.T., Werner, J.D., Asami, T., Berry, C.C., Weigel, D., Chory, J., 2002. Quantitative trait loci controlling light and hormone response in two accessions of Arabidopsis thaliana. Genetics 160, 683-696.

Botto, J., Sánchez, R., Casal, J., 1995. Role of phytochrome B in the induction of seed germination by light in Arabidopsis thaliana. J Plant Physiol 146, 307-312.

Botto, J.F., Alonso-Blanco, C., Garzarón, I., Sánchez, R.A., Casal, J.J., 2003. The Cape Verde Islands allele of cryptochrome 2 enhances cotyledon unfolding in the absence of blue light in Arabidopsis. Plant Physiol 133, 1547-1556.

Botto, J.F., Sánchez, R.A., Whitelam, G.C., Casal, J.J., 1996. Phytochrome A mediates the promotion of seed germination by very low fluences of light and canopy shade light in Arabidopsis. Plant Physiol 110, 439-444.

Bouyer, D., Roudier, F., Heese, M., Andersen, E.D., Gey, D., Nowack, M.K., Goodrich, J., Renou, J.-P., Grini, P.E., Colot, V., Schnittger, A., 2011. Polycomb repressive complex 2 controls the embryo-to-seedling phase transition. PLoS Genet 7, e1002014. 
Briggs, W.R., 2014. Phototropism: some history, some puzzles, and a look ahead. Plant Physiol $164,13-23$.

Brown, D.E., Rashotte, A.M., Murphy, A.S., Normanly, J., Tague, B.W., Peer, W.A., Taiz, L., Muday, G.K., 2001. Flavonoids act as negative regulators of auxin transport in vivo in Arabidopsis. Plant Physiol 126, 524-535.

Buer, C.S., Muday, G.K., 2004. The transparent testa4 mutation prevents flavonoid synthesis and alters auxin transport and the response of Arabidopsis roots to gravity and light. Plant Cell $16,1191-1205$.

Burchard, P., Bilger, W., Weissenböck, G., 2000. Contribution of hydroxycinnamates and flavonoids to epidermal shielding of UV-A and UV-B radiation in developing rye primary leaves as assessed by ultraviolet-induced chlorophyll fluorescence measurements. Plant Cell Environ 23, 1373-1380.

Busch, A.W.U., Montgomery, B.L., 2015. Interdependence of tetrapyrrole metabolism, the generation of oxidative stress and the mitigative oxidative stress response. Redox Biol 4, 260271.

Catala, R., Ouyang, J., Abreu, I.A., Hu, Y., Seo, H., Zhang, X., Chua, N.H., 2007. The Arabidopsis E3 SUMO ligase SIZ1 regulates plant growth and drought responses. Plant Cell 19, 2952-2966.

Chacón, I.D.-1.-C., Riley-Saldaña, C.A., González-Esquinca, A.R., 2013. Secondary metabolites during early development in plants. Phytochem Rev 12, 47-64. 
Chen, D., Xu, G., Tang, W., Jing, Y., Ji, Q., Fei, Z., Lin, R., 2013. Antagonistic basic helix-loophelix/bZIP transcription factors form transcriptional modules that integrate light and reactive oxygen species signaling in Arabidopsis. Plant Cell 25, 1657-1673.

Chen, H., Zhang, J., Neff, M.M., Hong, S.-W., Zhang, H., Deng, X.-W., Xiong, L., 2008. Integration of light and abscisic acid signaling during seed germination and early seedling development. Proceedings of the National Academy of Sciences of the United States of America $105,4495-4500$.

Chen, M., Thelen, J.J., 2010. The plastid isoform of triose phosphate isomerase is required for the postgerminative transition from heterotrophic to autotrophic growth in Arabidopsis. Plant Cell 22, 77-90.

Cho, J.-N., Ryu, J.-Y., Jeong, Y.-M., Park, J., Song, J.-J., Amasino, Richard M., Noh, B., Noh, Y.-S., 2012. Control of seed germination by light-induced histone arginine demethylation activity. Dev Cell 22, 736-748.

Chory, J., Reinecke, D., Sim, S., Washburn, T., Brenner, M., 1994. A role for cytokinins in deetiolation in Arabidopsis (det mutants have an altered response to cytokinins). Plant Physiol 104, $339-347$.

Christie, J.M., Yang, H., Richter, G.L., Sullivan, S., Thomson, C.E., Lin, J., Titapiwatanakun, B., Ennis, M., Kaiserli, E., Lee, O.R., Adamec, J., Peer, W.A., Murphy, A.S., 2011. phot1 Inhibition of ABCB19 primes lateral auxin fluxes in the shoot apex required for phototropism. PLoS Biol 9, e1001076. 
Chun, L., Kawakami, A., Christopher, D.A., 2001. Phytochrome A mediates blue light and UVA-dependent chloroplast gene transcription in green leaves. Plant Physiol 125, 1957-1966.

Clouse, S.D., 2011. Brassinosteroids. The Arabidopsis Book 9, e0151.

Corbineau, F., Xia, Q., Bailly, C., El-Maarouf-Bouteau, H., 2014. Ethylene, a key factor in the regulation of seed dormancy. Front Plant Sci 5, doi: 10.3389/fpls.2014.00539

Cutler, S.R., Rodriguez, P.L., Finkelstein, R.R., Abrams, S.R., 2010. Abscisic acid: Emergence of a core signaling Nnetwork. Ann Rev Plant Biol 61, 651-679.

de Lucas, M., Daviere, J.M., Rodriguez-Falcon, M., Pontin, M., Iglesias-Pedraz, J.M., Lorrain, S., Fankhauser, C., Blazquez, M.A., Titarenko, E., Prat, S., 2008. A molecular framework for light and gibberellin control of cell elongation. Nature 451, 480-484.

de Lucas, M., Prat, S., 2014. PIFs get BRright: PHYTOCHROME INTERACTING FACTORs as integrators of light and hormonal signals. New Phytol 202, 1126-1141.

Dehesh, K., Franci, C., Parks, B.M., Seeley, K.A., Short, T.W., Tepperman, J.M., Quail, P.H., 1993. Arabidopsis HY8 locus encodes phytochrome A. Plant Cell 5, 1081-1088.

Dekkers, B.J.W., Schuurmans, J.A.M.J., Smeekens, S.C.M., 2008. Interaction between sugar and abscisic acid signalling during early seedling development in Arabidopsis. Plant Mol Biol 67, $151-167$.

Delker, C., Pöschl, Y., Raschke, A., Ullrich, K., Ettingshausen, S., Hauptmann, V., Grosse, I., Quint, M., 2010. Natural variation of transcriptional auxin response networks in Arabidopsis thaliana. Plant Cell 22, 2184-2200. 
Delker, C., Quint, M., 2011. Expression level polymorphisms: heritable traits shaping natural variation. Trends Plant Sci 16, 481-488.

Duque, P., Chua, N.-H., 2003. IMB1, a bromodomain protein induced during seed imbibition, regulates ABA- and phyA-mediated responses of germination in Arabidopsis. Plant J 35, 787799.

Durrant, J.R., Giorgi, L.B., Barber, J., Klug, D.R., Porter, G., 1990. Characterisation of triplet states in isolated Photosystem II reaction centres: Oxygen quenching as a mechanism for photodamage. Biochim Biophys Acta 1017, 167-175.

Eastmond, P.J., 2006. SUGAR-DEPENDENT1 encodes a patatin domain triacylglycerol lipase that initiates storage oil breakdown in germinating Arabidopsis seeds. Plant Cell 18, 665-675.

El-Maarouf-Bouteau, H., Bailly, C., 2008. Oxidative signaling in seed germination and dormancy. Plant Signal Behav 3, 175-182.

El-Maarouf-Bouteau, H., Sajjad, Y., Bazin, J., Langlade, N., Cristescu, S.M., Balzergue, S., Baudouin, E., Bailly, C., 2015. Reactive oxygen species, abscisic acid and ethylene interact to regulate sunflower seed germination. Plant Cell Environ 38, 364-374.

Eveland, A.L., Jackson, D.P., 2012. Sugars, signalling, and plant development. J Exp Bot 63, 3367-3377.

Farré, E.M., Weise, S.E., 2012. The interactions between the circadian clock and primary metabolism. Curr Opin Plant Biol 15, 293-300. 
Favory, J.J., Stec, A., Gruber, H., Rizzini, L., Oravecz, A., Funk, M., Albert, A., Cloix, C., Jenkins, G.I., Oakeley, E.J., Seidlitz, H.K., Nagy, F., Ulm, R., 2009. Interaction of COP1 and UVR8 regulates UV-B-induced photomorphogenesis and stress acclimation in Arabidopsis. EMBO J 28, 591-601.

Feng, S., Martinez, C., Gusmaroli, G., Wang, Y., Zhou, J., Wang, F., Chen, L., Yu, L., IglesiasPedraz, J.M., Kircher, S., Schafer, E., Fu, X., Fan, L.M., Deng, X.W., 2008. Coordinated regulation of Arabidopsis thaliana development by light and gibberellins. Nature 451, 475-479.

Fierro, A.C., Leroux, O., De Coninck, B., Cammue, B.P., Marchal, K., Prinsen, E., Van Der Straeten, D., Vandenbussche, F., 2014. Ultraviolet-B radiation stimulates downward leaf curling in Arabidopsis thaliana. Plant Physiol Biochem, doi:10.1016/j.plaphy.2014.1012.1012.

Folta, K.M., Pontin, M.A., Karlin-Neumann, G., Bottini, R., Spalding, E.P., 2003. Genomic and physiological studies of early cryptochrome 1 action demonstrate roles for auxin and gibberellin in the control of hypocotyl growth by blue light. Plant J 36, 203-214.

Folta, K.M., Spalding, E.P., 2001. Unexpected roles for cryptochrome 2 and phototropin revealed by high-resolution analysis of blue light-mediated hypocotyl growth inhibition. Plant J $26,471-478$.

Forsman, A., 2014. Rethinking phenotypic plasticity and its consequences for individuals, populations and species. Heredity 2014, 1-9.

Franklin, K.A., Praekelt, U., Stoddart, W.M., Billingham, O.E., Halliday, K.J., Whitelam, G.C., 2003. Phytochromes B, D, and E act redundantly to control multiple physiological responses in Arabidopsis. Plant Physiol 131, 1340-1346. 
Franklin, K.A., Quail, P.H., 2010. Phytochrome functions in Arabidopsis development. J Exp Bot $61,11-24$.

Gupta, R., Chakrabarty, S.K., 2013. Gibberellic acid in plant. Plant signaling \& behavior 8, e25504.

Halliday, K.J., Martínez-García, J.F., Josse, E.-M., 2009. Integration of light and auxin signaling. Cold Spring Harb Perspect Biol 1, a001586.

Hayes, S., Velanis, C.N., Jenkins, G.I., Franklin, K.A., 2014. UV-B detected by the UVR8 photoreceptor antagonizes auxin signaling and plant shade avoidance. Proc Natl Acad Sci U S A 111, 11894-11899.

Hennig, L., Poppe, C., Sweere, U., Martin, A., Schafer, E., 2001. Negative interference of endogenous phytochrome B with phytochrome A function in Arabidopsis. Plant Physiol 125, 1036-1044.

Hennig, L., Stoddart, W.M., Dieterle, M., Whitelam, G.C., Schäfer, E., 2002. Phytochrome E controls light-induced germination of Arabidopsis. Plant Physiol 128, 194-200.

Heschel, M.S., Butler, C.M., Barua, D., Chiang, G.C.K., Wheeler, A., Sharrock, R.A., Whitelam, G.C., Donohue, K., 2008. New roles of phytochromes during seed germination. Int J Plant Sci $169,531-540$.

Heschel, M.S., Selby, J., Butler, C., Whitelam, G.C., Sharrock, R.A., Donohue, K., 2007. A new role for phytochromes in temperature- dependent germination. New Phytol 174, 735-741. 
Hogewoning, S.W., Trouwborst, G., Maljaars, H., Poorter, H., van leperen, W., Harbinson, J., 2010. Blue light dose-responses of leaf photosynthesis, morphology, and chemical composition of Cucumis sativus grown under different combinations of red and blue light. J Ex Bot 61, 31073117.

Hohm, T., Preuten, T., Fankhauser, C., 2013. Phototropism: Translating light into directional growth. Am J Bot 100, 47-59.

Holman, T.J., Jones, P.D., Russell, L., Medhurst, A., Úbeda Tomás, S., Talloji, P., Marquez, J., Schmuths, H., Tung, S.-A., Taylor, I., Footitt, S., Bachmair, A., Theodoulou, F.L., Holdsworth, M.J., 2009. The N-end rule pathway promotes seed germination and establishment through removal of ABA sensitivity in Arabidopsis. Proc Natl Acad Sci U S A 106, 4549-4554.

Huang, X., Yang, P., Ouyang, X., Chen, L., Deng, X.W., 2014. Photoactivated UVR8-COP1 module determines photomorphogenic UV-B signaling output in Arabidopsis. PLoS Genet 10, e1004218.

Jaenisch, R., Bird, A., 2003. Epigenetic regulation of gene expression: how the genome integrates intrinsic and environmental signals. Nat Genet 33, 245-254.

Jensen, P.J., Hangarter, R.P., Estelle, M., 1998. Auxin transport is required for hypocotyl elongation in light-grown but not dark-grown Arabidopsis. Plant Physiol 116, 455-462.

Jia, H., Suzuki, M., McCarty, D.R., 2014. Regulation of the seed to seedling developmental phase transition by the LAFL and VAL transcription factor networks. Wiley Interdiscip Rev Dev Biol 3, 135-145. 
Jiao, Y., Ma, L., Strickland, E., Deng, X.W., 2005. Conservation and divergence of lightregulated genome expression patterns during seedling development in rice and Arabidopsis. Plant Cell 17, 3239-3256.

Johnson, E., Bradley, M., Harberd, N.P., Whitelam, G.C., 1994. Photoresponses of light-grown phyA mutants of Arabidopsis. Plant Physiol 105, 141-149.

Joo, J.H., Bae, Y.S., Lee, J.S., 2001. Role of auxin-induced reactive oxygen species in root gravitropism. Plant Physiol 126, 1055-1060.

Joo, J.H., Yoo, H.J., Hwang, I., Lee, J.S., Nam, K.H., Bae, Y.S., 2005. Auxin-induced reactive oxygen species production requires the activation of phosphatidylinositol 3-kinase. FEBS Lett $579,1243-1248$.

Joseph, M.P., Papdi, C., Kozma-Bognár, L., Nagy, I., López-Carbonell, M., Rigó, G., Koncz, C., Szabados, L., 2014. The Arabidopsis ZINC FINGER PROTEIN3 interferes with abscisic acid and light signaling in seed germination and plant development. Plant Physiol 165, 1203-1220.

Junker, A., Mönke, G., Rutten, T., Keilwagen, J., Seifert, M., Thi, T.M.N., Renou, J.-P., Balzergue, S., Viehöver, P., Hähnel, U., Ludwig-Müller, J., Altschmied, L., Conrad, U., Weisshaar, B., Bäumlein, H., 2012. Elongation-related functions of LEAFY COTYLEDON1 during the development of Arabidopsis thaliana. Plant J 71, 427-442.

Kami, C., Lorrain, S., Hornitschek, P., Fankhauser, C., 2010. Light-regulated plant growth and development. Curr Top Dev Biol 91, 29-66.

Kieber, J.J., Schaller, G.E., 2014. Cytokinins. Arabidopsis Book 12, e0168. 
Kravtsov, A.K., Zubo, Y.O., Yamburenko, M.V., Kulaeva, O.N., Kusnetsov, V.V., 2011.

Cytokinin and abscisic acid control plastid gene transcription during barley seedling deetiolation. Plant Growth Regul 64, 173-183.

Krieger-Liszkay, A., 2005. Singlet oxygen production in photosynthesis. J Exp Bot 56, 337-346.

Kubasek, W.L., Shirley, B.W., McKillop, A., Goodman, H.M., Briggs, W., Ausubel, F.M., 1992. Regulation of flavonoid biosynthetic genes in germinating Arabidopsis seedlings. Plant Cell 4, 1229-1236.

Kucera, B., Cohn, M.A., Leubner-Metzger, G., 2005. Plant hormone interactions during seed dormancy release and germination. Seed Sci Res 15, 281-307.

Kuhn, B.M., Geisler, M., Bigler, L., Ringli, C., 2011. Flavonols accumulate asymmetrically and affect auxin transport in Arabidopsis. Plant Physiol 156, 585-595.

Kurepin, L.V., Walton, L.J., Hayward, A., Emery, R.J.N., Pharis, R.P., Reid, D.M., 2012. Interactions between plant hormones and light quality signaling in regulating the shoot growth of Arabidopsis thaliana seedlings. Botany 90, 237-246.

Kusnetsov, V., Herrmann, R., Kulaeva, O., Oelmüller, R., 1998. Cytokinin stimulates and abscisic acid inhibits greening of etiolated Lupinus luteus cotyledons by affecting the expression of the light-sensitive protochlorophyllide oxidoreductase. Mol Genet Genomics 259, 21-28.

Landry, L.G., Chapple, C.C., Last, R.L., 1995. Arabidopsis mutants lacking phenolic sunscreens exhibit enhanced ultraviolet-B injury and oxidative damage. Plant Physiol 109, 1159-1166. 
Lapik, Y.R., Kaufman, L.S., 2003. The Arabidopsis cupin domain protein AtPirin1 interacts with the G protein alpha-subunit GPA1 and regulates seed germination and early seedling development. Plant Cell 15, 1578-1590.

Lariguet, P., Ranocha, P., De Meyer, M., Barbier, O., Penel, C., Dunand, C., 2013. Identification of a hydrogen peroxide signalling pathway in the control of light-dependent germination in Arabidopsis. Planta 238, 381-395.

Lau, O.S., Deng, X.W., 2010. Plant hormone signaling lightens up: integrators of light and hormones. Curr Opin Plant Biol 13, 571-577.

Leivar, P., Quail, P.H., 2011. PIFs: pivotal components in a cellular signaling hub. Trends Plant Sci 16, 19-28.

Lepiniec, L., Debeaujon, I., Routaboul, J.M., Baudry, A., Pourcel, L., Nesi, N., Caboche, M., 2006. Genetics and biochemistry of seed flavonoids. Annu Rev Plant Biol 57, 405-430.

Lewis, D.R., Ramirez, M.V., Miller, N.D., Vallabhaneni, P., Ray, W.K., Helm, R.F., Winkel, B.S., Muday, G.K., 2011. Auxin and ethylene induce flavonol accumulation through distinct transcriptional networks. Plant Physiol 156, 144-164.

Leymarie, J., Vitkauskaité, G., Hoang, H.H., Gendreau, E., Chazoule, V., Meimoun, P., Corbineau, F., El-Maarouf-Bouteau, H., Bailly, C., 2011. Role of reactive oxygen species in the regulation of Arabidopsis seed dormancy. Plant Cell Physiol 53, 96-106.

Li, B., Carey, M., Workman, J.L., 2007. The role of chromatin during transcription. Cell 128, 707-719. 
Li, J., Chory, J., 1999. Brassinosteroid actions in plants. J Exp Bot 50, 275-282.

Lian, H.-L., He, S.-B., Zhang, Y.-C., Zhu, D.-M., Zhang, J.-Y., Jia, K.-P., Sun, S.-X., Li, L., Yang, H.-Q., 2011. Blue-light-dependent interaction of cryptochrome 1 with SPA1 defines a dynamic signaling mechanism. Genes Dev 25, 1023-1028.

Lin, R., Tang, W., 2014. Cross talk between light and ABA signaling, in: Zhang, D.-P. (Ed.), Abscisic Acid: Metabolism, Transport and Signaling. Springer Netherlands, pp 255-269.

Liszkay, A., van der Zalm, E., Schopfer, P., 2004. Production of reactive oxygen intermediates $\left(\mathrm{O} 2^{-}-, \mathrm{H} 2 \mathrm{O} 2\right.$, and $\left.{ }^{\circ} \mathrm{OH}\right)$ by maize roots and their role in wall loosening and elongation growth. Plant Physiol 136, 3114-3123.

Liu, B., Zuo, Z., Liu, H., Liu, X., Lin, C., 2011. Arabidopsis cryptochrome 1 interacts with SPA1 to suppress COP1 activity in response to blue light. Genes Dev 25, 1029-1034.

Luo, X.M., Lin, W.H., Zhu, S., Zhu, J.Y., Sun, Y., Fan, X.Y., Cheng, M., Hao, Y., Oh, E., Tian, M., Liu, L., Zhang, M., Xie, Q., Chong, K., Wang, Z.Y., 2010. Integration of light- and brassinosteroid-signaling pathways by a GATA transcription factor in Arabidopsis. Dev Cell 19, $872-883$.

Maloof, J.N., Borevitz, J.O., Dabi, T., Lutes, J., Nehring, R.B., Redfern, J.L., Trainer, G.T., Wilson, J.M., Asami, T., Berry, C.C., 2001. Natural variation in light sensitivity of Arabidopsis. Nat Genet 29, 441-446.

Marín-Navarro, J., Manuell, A., Wu, J., P. Mayfield, S., 2007. Chloroplast translation regulation. Photosyn Res 94, 359-374. 
Mellenthin, M., Ellersiek, U., Börger, A., Baier, M., 2014. Expression of the Arabidopsis Sigma Factor SIG5 Is photoreceptor and photosynthesis controlled. Plants 3, 359-391.

Miransari, M., Smith, D.L., 2014. Plant hormones and seed germination. Environ Exp Bot 99, $110-121$.

Mitchell-Olds, T., 2001. Arabidopsis thaliana and its wild relatives: a model system for ecology and evolution. Trends Ecol Evol 16, 693-700.

Moni, A., Lee, A.Y., Briggs, W.R., Han, I.S., 2015. The blue light receptor Phototropin 1 suppresses lateral root growth by controlling cell elongation. Plant Biol 17, 34-40.

Monte, E., Alonso, J.M., Ecker, J.R., Zhang, Y., Li, X., Young, J., Austin-Phillips, S., Quail, P.H., 2003. Isolation and characterization of $p h y C$ mutants in Arabidopsis reveals complex crosstalk between phytochrome signaling pathways. Plant Cell 15, 1962-1980.

Monte, E., Tepperman, J.M., Al-Sady, B., Kaczorowski, K.A., Alonso, J.M., Ecker, J.R., Li, X., Zhang, Y., Quail, P.H., 2004. The phytochrome-interacting transcription factor, PIF3, acts early, selectively, and positively in light-induced chloroplast development. Proc Natl Acad Sci U S A 101, 16091-16098.

Moon, J., Zhu, L., Shen, H., Huq, E., 2008. PIF1 directly and indirectly regulates chlorophyll biosynthesis to optimize the greening process in Arabidopsis. Proc Natl Acad Sci U S A 105, 9433-9438.

Murphy, A., Peer, W.A., Taiz, L., 2000. Regulation of auxin transport by aminopeptidases and endogenous flavonoids. Planta 211, 315-324. 
Muscarella, R., Uriarte, M., Forero-Montaña, J., Comita, L.S., Swenson, N.G., Thompson, J., Nytch, C.J., Jonckheere, I., Zimmerman, J.K., 2013. Life-history trade-offs during the seed-toseedling transition in a subtropical wet forest community. J Ecol 101, 171-182.

Nagata, N., Min, Y., Nakano, T., Asami, T., Yoshida, S., 2000. Treatment of dark-grown Arabidopsis thaliana with a brassinosteroid-biosynthesis inhibitor, brassinazole, induces some characteristics of light-grown plants. Planta 211, 781-790.

Nagatani, A., Reed, J.W., Chory, J., 1993. Isolation and initial characterization of Arabidopsis mutants that are deficient in phytochrome A. Plant Physiol 102, 269-277.

Nakano, T., Kimura, T., Kaneko, I., Nagata, N., Matsuyama, T., Asami, T., Yoshida, S., 2001. Molecular mechanism of chloroplast development regulated by plant hormones. Riken Rev 41 .

Neff, M.M., Nguyen, S.M., Malancharuvil, E.J., Fujioka, S., Noguchi, T., Seto, H., Tsubuki, M., Honda, T., Takatsuto, S., Yoshida, S., Chory, J., 1999. BAS1: A gene regulating brassinosteroid levels and light responsiveness in Arabidopsis. Proc Natl Acad Sci U S A 96, 15316-15323.

Nemhauser, J.L., Hong, F., Chory, J., 2006. Different plant hormones regulate similar processes through largely nonoverlapping transcriptional responses. Cell 126, 467-475.

Oh, E., Yamaguchi, S., Hu, J., Yusuke, J., Jung, B., Paik, I., Lee, H.-S., Sun, T.-p., Kamiya, Y., Choi, G., 2007. PIL5, a phytochrome-interacting bHLH protein, regulates gibberellin responsiveness by binding directly to the GAI and RGA promoters in Arabidopsis seeds. Plant Cell 19, 1192-1208. 
Oh, E., Yamaguchi, S., Kamiya, Y., Bae, G., Chung, W.-I., Choi, G., 2006. Light activates the degradation of PIL5 protein to promote seed germination through gibberellin in Arabidopsis. Plant J 47, 124-139.

Oh, S., Montgomery, B.L., 2013. Phytochrome-induced SIG2 expression contributes to photoregulation of phytochrome signaling and photomorphogenesis in Arabidopsis thaliana. J Exp Bot 64, 5457-5472.

Oh, S., Montgomery, B.L., 2014. Phytochrome-dependent coordinate control of distinct aspects of nuclear and plastid gene expression during anterograde signalling and photomorphogenesis. Front Plant Sci 5, 171.

Oh, S., Warnasooriya, S.N., Montgomery, B.L., 2013. Downstream effectors of light- and phytochrome-dependent regulation of hypocotyl elongation in Arabidopsis thaliana. Plant Mol Biol 81, 627-640.

Onda, Y., Yagi, Y., Saito, Y., Takenaka, N., Toyoshima, Y., 2008. Light induction of Arabidopsis SIG1 and SIG5 transcripts in mature leaves: differential roles of cryptochrome 1 and cryptochrome 2 and dual function of SIG5 in the recognition of plastid promoters. Plant J 55, 968-978.

Orozco-Nunnelly, D.A., Muhammad, D., Liakaite, V., Green, S.J., Warpeha, K.M., 2014a. Pirin1 Is a non-circadian regulated transcript and protein, but highly responsive to light/dark periods in the seed-to-seedling transition in Arabidopsis thaliana. Plant Mol Biol Rep, doi:10.\&\#8203;1007/\&\#8203;s11105-014-0826-X.. 
Orozco-Nunnelly, D.A., Muhammad, D., Mezzich, R., Lee, B.-S., Jayathilaka, L., Kaufman, L.S., Warpeha, K.M., 2014b. Pirin1 (PRN1) is a multifunctional protein that regulates quercetin, and impacts specific light and UV responses in the seed-to-seedling transition of Arabidopsis thaliana. PLoS ONE 9, e93371.

Parks, B.M., Quail, P.H., 1993. hy8, a new class of Arabidopsis long hypocotyl mutants deficient in functional phytochrome A. Plant Cell 5, 39-48.

Parks, B.M., Spalding, E.P., 1999. Sequential and coordinated action of phytochromes A and B during Arabidopsis stem growth revealed by kinetic analysis. Proc Natl Acad Sci U S A 96, $14142-14146$.

Peer, W.A., Brown, D.E., Tague, B.W., Muday, G.K., Taiz, L., Murphy, A.S., 2001. Flavonoid accumulation patterns of transparent testa mutants of Arabidopsis. Plant Physiol 126, 536-548.

Peer, W.A., Cheng, Y., Murphy, A.S., 2013. Evidence of oxidative attenuation of auxin signalling. J Exp Bot 64, 2629-2639.

Perilli, S., Moubayidin, L., Sabatini, S., 2010. The molecular basis of cytokinin function. Curr Opin Plant Biol 13, 21-26.

Peter, H., Stephen, G.T., 2012. Gibberellin biosynthesis and its regulation. Biochem J 444, 1125.

Phillips, T., Hoopes, L., 2008. Transcription factors and transcriptional control in eukaryotic cells. Nature Education 1, 119. 
Pogson, B.J., Albrecht, V., 2011. Genetic dissection of chloroplast biogenesis and development: an overview. Plant Physiol 155, 1545-1551.

Poorter, L., 2007. Are species adapted to their regeneration niche, adult niche, or both? Am Nat $169,433-442$.

Reed, J.W., Nagatani, A., Elich, T.D., Fagan, M., Chory, J., 1994. Phytochrome A and Phytochrome B have overlapping but distinct functions in Arabidopsis development. Plant Physiol 104, 1139-1149.

Reed, J.W., Nagpal, P., Poole, D.S., Furuya, M., Chory, J., 1993. Mutations in the gene for the red/far-red light receptor phytochrome B alter cell elongation and physiological responses throughout Arabidopsis development. Plant Cell 5, 147-157.

Remington, David L., Purugganan, Michael D., 2003. Candidate genes, quantitative trait loci, and functional trait evolution in plants. Int J Plant Sci 164, S7-S20.

Rizzini, L., Favory, J.-J., Cloix, C., Faggionato, D., O'Hara, A., Kaiserli, E., Baumeister, R., Schäfer, E., Nagy, F., Jenkins, G.I., Ulm, R., 2011. Perception of UV-B by the Arabidopsis UVR8 Protein. Science 332, 103-106.

Rolland, F., Baena-Gonzalez, E., Sheen, J., 2006. Sugar sensing and signaling in plants: conserved and novel mechanisms. Annu Rev Plant Biol 57, 675-709.

Rozema, J., Björn, L.O., Bornman, J.F., Gaberscik, A., Hader, D.P., Trost, T., Germ, M., Klisch, M., Gröniger, A., Sinha, R.P., Lebert, M., He, Y.Y., Buffoni-Hall, R., de Bakker, N.V., van de Staaij, J., Meijkamp, B.B., 2002. The role of UV-B radiation in aquatic and terrestrial 
ecosystems--an experimental and functional analysis of the evolution of UV-absorbing compounds. J Photochem Photobiol B 66, 2-12.

Ruppel, N.J., Hangarter, R.P., 2007. Mutations in a plastid-localized elongation factor G alter early stages of plastid development in Arabidopsis thaliana. BMC Plant Biol 7, 37.

Ruppel, N.J., Logsdon, C.A., Whippo, C.W., Inoue, K., Hangarter, R.P., 2011. A mutation in Arabidopsis SEEDLING PLASTID DEVELOPMENT1 affects plastid differentiation in embryoderived tissues during seedling growth. Plant Physiol 155, 342-353.

Saijo, Y., Sullivan, J.A., Wang, H., Yang, J., Shen, Y., Rubio, V., Ma, L., Hoecker, U., Deng, X.W., 2003. The COP1-SPA1 interaction defines a critical step in phytochrome A-mediated regulation of HY5 activity. Genes Dev 17, 2642-2647.

Sakai, T., Kagawa, T., Kasahara, M., Swartz, T.E., Christie, J.M., Briggs, W.R., Wada, M., Okada, K., 2001. Arabidopsis nph1 and npl1: Blue light receptors that mediate both phototropism and chloroplast relocation. Proc Natl Acad Sci U S A 98, 6969-6974.

Sakata, Y., Komatsu, K., Takezawa, D., 2014. ABA as a Universal Plant Hormone, in: Lüttge, U., Beyschlag, W., Cushman, J. (Eds.), Progress in Botany. Springer Berlin Heidelberg, pp 5796.

Salisbury, F.J., Hall, A., Grierson, C.S., Halliday, K.J., 2007. Phytochrome coordinates Arabidopsis shoot and root development. Plant J 50, 429-438.

Saunders, J.A., McClure, J.W., 1976. The distribution of flavonoids in chloroplasts of twenty five species of vascular plants. Phytochemistry 15, 809-810. 
Sawada, Y., Aoki, M., Nakaminami, K., Mitsuhashi, W., Tatematsu, K., Kushiro, T., Koshiba, T., Kamiya, Y., Inoue, Y., Nambara, E., Toyomasu, T., 2008. Phytochrome- and gibberellinmediated regulation of abscisic acid metabolism during germination of photoblastic lettuce seeds. Plant Physiol 146, 1386-1396.

Schaller, G.E., Bishopp, A., Kieber, J.J., 2015. The yin-yang of hormones: Cytokinin and auxin interactions in plant development. Plant Cell, doi: http://dx.doi.org/10.1105/tpc.1114.133595.

Schmülling, T., Schäfer, S., Romanov, G., 1997. Cytokinins as regulators of gene expression. Physiol Plant 100, 505-519.

Schopfer, P., 2001. Hydroxyl radical-induced cell-wall loosening in vitro and in vivo: implications for the control of elongation growth. Plant J 28, 679-688.

Schopfer, P., Liszkay, A., 2006. Plasma membrane-generated reactive oxygen intermediates and their role in cell growth of plants. Biofactors 28, 73-81.

Seo, H.S., Yang, J.-Y., Ishikawa, M., Bolle, C., Ballesteros, M.L., Chua, N.-H., 2003. LAF1 ubiquitination by COP1 controls photomorphogenesis and is stimulated by SPA1. Nature 423, 995-999.

Seo, M., Hanada, A., Kuwahara, A., Endo, A., Okamoto, M., Yamauchi, Y., North, H., MarionPoll, A., Sun, T.-p., Koshiba, T., Kamiya, Y., Yamaguchi, S., Nambara, E., 2006. Regulation of hormone metabolism in Arabidopsis seeds: phytochrome regulation of abscisic acid metabolism and abscisic acid regulation of gibberellin metabolism. Plant J 48, 354-366. 
Seo, M., Nambara, E., Choi, G., Yamaguchi, S., 2009. Interaction of light and hormone signals in germinating seeds. Plant Mol Biol 69, 463-472.

Sheahan, J.J., 1996. Sinapate esters provide greater UV-B attenuation than flavonoids in Arabidopsis thaliana (Brassicaceae). Am J Bot, 679-686.

Sheerin, D.J., Menon, C., zur Oven-Krockhaus, S., Enderle, B., Zhu, L., Johnen, P., Schleifenbaum, F., Stierhof, Y.-D., Huq, E., Hiltbrunner, A., 2015. Light-activated phytochrome A and B interact with members of the SPA family to promote photomorphogenesis in Arabidopsis by reorganizing the COP1/SPA complex. Plant Cell 27, 189-201.

Shimada, H., Mochizuki, M., Ogura, K., Froehlich, J.E., Osteryoung, K.W., Shirano, Y., Shibata, D., Masuda, S., Mori, K., Takamiya, K.-i., 2007. Arabidopsis cotyledon-specific chloroplast biogenesis factor CYO1 is a protein disulfide isomerase. Plant Cell 19, 3157-3169.

Shinomura, T., Nagatani, A., Chory, J., Furuya, M., 1994. The induction of seed germination in Arabidopsis thaliana is regulated principally by phytochrome B and secondarily by phytochrome A. Plant Physiol 104, 363-371.

Song, S., Dai, X., Zhang, W.-H., 2012. A rice F-box gene, OsFbx352, is involved in glucosedelayed seed germination in rice. J Exp Bot 63, 5559-5568.

Staneloni, R.J., Rodriguez-Batiller, M.J., Casal, J.J., 2008. Abscisic acid, high-light, and oxidative stress down-regulate a photosynthetic gene via a promoter motif not involved in phytochrome-mediated transcriptional regulation. Mol Plant 1, 75-83. 
Stitt, M., Zeeman, S.C., 2012. Starch turnover: pathways, regulation and role in growth. Curr Opin Plant Biol 15, 282-292.

Stone, S.L., Williams, L.A., Farmer, L.M., Vierstra, R.D., Callis, J., 2006. KEEP ON GOING, a RING E3 ligase essential for Arabidopsis and development, is involved in abscisic acid signaling. Plant Cell 18, 3415-3428.

Sullivan, J.H., Muhammad, D., Warpeha, K.M., 2014. Phenylalanine is required to promote specific developmental responses and prevents cellular damage in response to ultraviolet light in Soybean (Glycine max) during the seed-to-seedling transition. PLoS ONE 9, e112301.

Symons, G., Reid, J., 2003. Interactions between light and plant hormones during de-etiolation. J Plant Growth Regul 22, 3-14.

Thoge, T., Watanabe, M., Hoefgen, R., Fernie A., 2013. The evolution of the phenylpropanoid metabolism in the green lineage. Crit Rev Biochem Mol Biol 48, 123-152.

Thum, K.E., Kim, M., Christopher, D.A., Mullet, J.E., 2001. Cryptochrome 1, cryptochrome 2, and phytochrome A co-activate the chloroplast $p s b D$ blue light-responsive promoter. Plant Cell $13,2747-2760$.

Toyomasu, T., Kawaide, H., Mitsuhashi, W., Inoue, Y., Kamiya, Y., 1998. Phytochrome regulates gibberellin biosynthesis during germination of photoblastic lettuce seeds. Plant Physiol 118, 1517-1523. 
Turk, E.M., Fujioka, S., Seto, H., Shimada, Y., Takatsuto, S., Yoshida, S., Denzel, M.A., Torres, Q.I., Neff, M.M., 2003. CYP72B1 inactivates brassinosteroid hormones: an intersection between photomorphogenesis and plant steroid signal transduction. Plant Physiol 133, 1643-1653.

Turk, E.M., Fujioka, S., Seto, H., Shimada, Y., Takatsuto, S., Yoshida, S., Wang, H., Torres, Q.I., Ward, J.M., Murthy, G., Zhang, J., Walker, J.C., Neff, M.M., 2005. BAS1 and SOB7 act redundantly to modulate Arabidopsis photomorphogenesis via unique brassinosteroid inactivation mechanisms. Plant J 42, 23-34.

van Zanten, M., Zöll, C., Wang, Z., Philipp, C., Carles, A., Li, Y., Kornet, N.G., Liu, Y., Soppe, W.J.J., 2014. HISTONE DEACETYLASE 9 represses seedling traits in Arabidopsis thaliana dry seeds. Plant J 80, 475-488.

Vandenbussche, F., Habricot, Y., Condiff, A.S., Maldiney, R., Van der Straeten, D., Ahmad, M., 2007. HY5 is a point of convergence between cryptochrome and cytokinin signalling pathways in Arabidopsis thaliana. Plant J 49, 428-441.

Vandenbussche, F., Tilbrook, K., Fierro, A.C., Marchal, K., Poelman, D., Van Der Straeten, D., Ulm, R., 2014. Photoreceptor-mediated bending towards UV-B in Arabidopsis. Mol Plant 7, 1041-1052.

Wang, Y., Folta, K.M., 2013. Contributions of green light to plant growth and development. Am J Bot 100, 70-78.

Warpeha, K.M., Gibbons, J., Carol, A., Slusser, J., Tree, R., Durham, W., Kaufman, L.S., 2008. Adequate phenylalanine synthesis mediated by $\mathrm{G}$ protein is critical for protection from UV 
radiation damage in young etiolated Arabidopsis thaliana seedlings. Plant Cell Environ 31, 1756-1770.

Warpeha, K.M., Lateef, S.S., Lapik, Y., Anderson, M., Lee, B.S., Kaufman, L.S., 2006. Gprotein-coupled receptor 1, G-protein Galpha-subunit 1, and prephenate dehydratase 1 are required for blue light-induced production of phenylalanine in etiolated Arabidopsis. Plant Physiol 140, 844-855.

Warpeha, K.M., Park, Y.-D., Williamson, P.R., 2013. Susceptibility of intact germinating Arabidopsis thaliana to human fungal pathogens Cryptococcus neoformans and C. gattii. Appl Environ Microbiol 79, 2979-2988.

Warpeha, K.M., Upadhyay, S., Yeh, J., Adamiak, J., Hawkins, S.I., Lapik, Y.R., Anderson, M.B., Kaufman, L.S., 2007. The GCR1, GPA1, PRN1, NF-Y signal chain mediates both blue light and abscisic acid responses in Arabidopsis. Plant Physiol 143, 1590-1600.

Weigel, D., 2012. Natural variation in Arabidopsis: From molecular genetics to ecological genomics. Plant Physiol 158, 2-22.

Wellburn, F.A., Wellburn, A., 1973. Response of etiplasts in situ and in isolated suspensions to pre-illumination with various combinations of red, far-red and blue light. New Phytol 72, 55-60.

Wu, G., Cameron, J.N., Ljung, K., Spalding, E.P., 2010. A role for ABCB19-mediated polar auxin transport in seedling photomorphogenesis mediated by cryptochrome 1 and phytochrome B. Plant J 62, 179-191. 
Yamamoto, A., Kagaya, Y., Toyoshima, R., Kagaya, M., Takeda, S., Hattori, T., 2009.

Arabidopsis NF-YB subunits LEC1 and LEC1-LIKE activate transcription by interacting with seed-specific ABRE-binding factors. Plant J 58, 843-856.

Yamburenko, M.V., Zubo, Y.O., Vanková, R., Kusnetsov, V.V., Kulaeva, O.N., Börner, T., 2013. Abscisic acid represses the transcription of chloroplast genes. J Exp Bot 64, 4491-4502.

Yanovsky, M.J., Casal, J.J., Luppi, J.P., 1997. The VLF loci, polymorphic between ecotypes Landsberg erecta and Columbia, dissect two branches of phytochrome A signal transduction that correspond to very-low-fluence and high-irradiance responses. Plant J 12, 659-667.

Yuan, K., Wysocka-Diller, J., 2006. Phytohormone signalling pathways interact with sugars during seed germination and seedling development. J Exp Bot 57, 3359-3367.

Zeng, J., Wang, Q., Lin, J., Deng, K., Zhao, X., Tang, D., Liu, X., 2010. Arabidopsis cryptochrome-1 restrains lateral roots growth by inhibiting auxin transport. J Plant Physiol 167, $670-673$.

Zhang, T., Maruhnich, S.A., Folta, K.M., 2011. Green light induces shade avoidance symptoms. Plant Physiol 157, 1528-1536.

Zhang, X., Garreton, V., Chua, N.-H., 2005. The AIP2 E3 ligase acts as a novel negative regulator of ABA signaling by promoting ABI3 degradation. Genes Dev 19, 1532-1543.

Zhao, X., Yu, X., Foo, E., Symons, G.M., Lopez, J., Bendehakkalu, K.T., Xiang, J., Weller, J.L., Liu, X., Reid, J.B., Lin, C., 2007. A study of gibberellin homeostasis and cryptochromemediated blue light inhibition of hypocotyl elongation. Plant Physiol 145, 106-118. 
Zhao, Y., 2010. Auxin biosynthesis and its role in plant development. Ann Rev Plant Biol 61, 49-64.

Zhu, G., Ye, N., Zhang, J., 2009. Glucose-induced delay of seed germination in rice is mediated by the suppression of ABA catabolism rather than an enhancement of ABA biosynthesis. Plant Cell Physiol 50, 644-651.

Zhu, J.-Y., Sae-Seaw, J., Wang, Z.-Y., 2013. Brassinosteroid signalling. Development 140, 1615-1620.

Zuo, Z., Liu, H., Liu, B., Liu, X., Lin, C., 2011. Blue light-dependent interaction of CRY2 with SPA1 regulates COP1 activity and floral initiation in Arabidopsis. Curr Biol 21, 841-847. 
Table 1. Role of plant photoreceptors in seed-to seedling transition

\begin{tabular}{|c|c|c|c|}
\hline $\begin{array}{l}\text { Photoreceptor/circadian } \\
\text { component }\end{array}$ & $\begin{array}{l}\text { Primary } \\
\text { wavelengths } \\
\text { detected }\end{array}$ & Role(s) & Select reference(s) \\
\hline $\begin{array}{l}\text { phytochrome (phy) A } \\
\text { (phyA) }\end{array}$ & $\begin{array}{l}\text { red }(\mathrm{R}) / \text { far-red } \\
(\mathrm{FR})\end{array}$ & $\begin{array}{l}\text { FR-dependent seed } \\
\text { germination; de- } \\
\text { etiolation }\end{array}$ & $\begin{array}{l}\text { (Botto et al., 1996; } \\
\text { Dehesh et al., 1993; } \\
\text { Franklin et al., 2003; } \\
\text { Heschel et al., 2008; } \\
\text { Heschel et al., 2007; } \\
\text { Johnson et al., 1994; } \\
\text { Nagatani et al., 1993; } \\
\text { Parks and Quail, } \\
\text { 1993; Parks and } \\
\text { Spalding, 1999; Reed } \\
\text { et al., 1994; } \\
\text { Shinomura et al., } \\
\text { 1994) }\end{array}$ \\
\hline phyB & $\mathrm{R} / \mathrm{FR}$ & $\begin{array}{l}\text { R/FR-reversible } \\
\text { germination; de- } \\
\text { etiolation }\end{array}$ & $\begin{array}{l}\text { (Botto et al., 1995; } \\
\text { Franklin et al., 2003; } \\
\text { Hennig et al., 2001; } \\
\text { Heschel et al., 2008; } \\
\text { Heschel et al., 2007; } \\
\text { Parks and Spalding, }\end{array}$ \\
\hline
\end{tabular}




\begin{tabular}{|c|c|c|c|}
\hline & & & $\begin{array}{l}\text { 1999; Reed et al., } \\
\text { 1994; Reed et al., } \\
\text { 1993; Shinomura et } \\
\text { al., 1994) }\end{array}$ \\
\hline phyC & $\mathrm{R} / \mathrm{FR}$ & $\begin{array}{l}\text { inhibit germination; } \\
\text { de-etiolation }\end{array}$ & $\begin{array}{l}\text { (Arana et al., 2014; } \\
\text { Franklin et al., 2003; } \\
\text { Monte et al., 2003) }\end{array}$ \\
\hline phyD & $\mathrm{R} / \mathrm{FR}$ & $\begin{array}{l}\text { germination; de- } \\
\text { etiolation }\end{array}$ & $\begin{array}{l}\text { (Arana et al., 2014; } \\
\text { Franklin et al., 2003; } \\
\text { Hennig et al., 2001; } \\
\text { Heschel et al., 2008) }\end{array}$ \\
\hline phyE & $\mathrm{R} / \mathrm{FR}$ & $\begin{array}{l}\text { R/FR-reversible } \\
\text { germination; de- } \\
\text { etiolation }\end{array}$ & $\begin{array}{l}\text { (Arana et al., 2014; } \\
\text { Franklin et al., 2003; } \\
\text { Hennig et al., 2002; } \\
\text { Heschel et al., 2008; } \\
\text { Heschel et al., 2007) }\end{array}$ \\
\hline $\begin{array}{l}\text { cryptochrome (cry) } 1 \\
\text { (cry1) }\end{array}$ & $\begin{array}{l}\text { /blue } \\
\text { (B)/ultraviolet A } \\
\text { (UV-A) }\end{array}$ & de-etiolation & $\begin{array}{l}\text { (Ahmad et al., 1998; } \\
\text { Ahmad et al., 1995; } \\
\text { Folta and Spalding, } \\
\text { 2001) }\end{array}$ \\
\hline cry2 & $\mathrm{B} / \mathrm{UV}-\mathrm{A}$ & de-etiolation & $\begin{array}{l}\text { (Ahmad et al., 1998; } \\
\text { Folta and Spalding, } \\
\text { 2001) }\end{array}$ \\
\hline
\end{tabular}




\begin{tabular}{|l|l|l|l|}
\hline phototropin (phot) 1 & B/UV-A & $\begin{array}{l}\text { phototropism; } \\
\text { inhibition of hypocotyl } \\
\text { (phot1) }\end{array}$ & $\begin{array}{l}\text { (Folta and Spalding, } \\
\text { 2001; Sakai et al., } \\
\text { 2001) }\end{array}$ \\
\hline phot2 & B/UV-A & phototropism & (Sakai et al., 2001) \\
\hline UVR8 & UV-B & $\begin{array}{l}\text { photomorphogenesis; } \\
\text { UV-B stress } \\
\text { mitigation; } \\
\text { phototropism }\end{array}$ & $\begin{array}{l}\text { (Favory et al., 2009; } \\
\text { Huang et al., 2014; } \\
\text { Rizzini et al., 2011; } \\
\text { Vandenbussche et al., } \\
\text { 2014) }\end{array}$ \\
& & &
\end{tabular}


Table 2. Role of plant hormones in seed-to seedling transition

\begin{tabular}{|c|c|c|}
\hline Hormone & Role(s) & Reference(s) \\
\hline Abscisic acid (ABA) & $\begin{array}{l}\text { Inhibit germination, promote seed } \\
\text { dormancy (antagonizes GA andBR) }\end{array}$ & $\begin{array}{l}\text { Reviewed by (Cutler et al., } \\
\text { 2010; Miransari and Smith, } \\
\text { 2014; Sakata et al., 2014) }\end{array}$ \\
\hline $\begin{array}{l}\text { Gibberellin or } \\
\text { gibberellic acid (GA) }\end{array}$ & $\begin{array}{l}\text { Promote germination (through ABA } \\
\text { antagonism); promote stem } \\
\text { elongation and leaf expansion }\end{array}$ & $\begin{array}{l}\text { Reviewed by (Gupta and } \\
\text { Chakrabarty, 2013; Miransari } \\
\text { and Smith, 2014; Peter and } \\
\text { Stephen, 2012) }\end{array}$ \\
\hline Auxin & $\begin{array}{l}\text { Promote cellular elongation and root } \\
\text { initiation; promotes phototropism }\end{array}$ & $\begin{array}{l}\text { Reviewed by (Hohm et al., } \\
\text { 2013; Miransari and Smith, } \\
\text { 2014; Schaller et al., 2015; } \\
\text { Zhao, 2010) }\end{array}$ \\
\hline Ethylene & $\begin{array}{l}\text { Promote germination (partially } \\
\text { through ABA antagonism); promote } \\
\text { growth and differentiation of shoots } \\
\text { and roots }\end{array}$ & $\begin{array}{l}\text { Reviewed by (Corbineau et } \\
\text { al., 2014; Miransari and } \\
\text { Smith, 2014) }\end{array}$ \\
\hline Brassinosteroid (BR) & $\begin{array}{l}\text { Promote germination (through ABA } \\
\text { antagonism); promote seedling } \\
\text { elongation; inhibit chloroplast } \\
\text { development }\end{array}$ & $\begin{array}{l}\text { Reviewed by (Clouse, 2011; } \\
\text { Miransari and Smith, 2014; } \\
\text { Zhu et al., 2013) }\end{array}$ \\
\hline Cytokinin & $\begin{array}{l}\text { Promote embryonic cell division and } \\
\text { root elongation; promote chloroplast }\end{array}$ & $\begin{array}{l}\text { Reviewed by (Binns, 1994; } \\
\text { Kieber and Schaller, 2014; }\end{array}$ \\
\hline
\end{tabular}




\begin{tabular}{|l|l|l|}
\hline & development & $\begin{array}{l}\text { Miransari and Smith, 2014; } \\
\text { Perilli et al., 2010; Schaller et } \\
\text { al., 2015) }\end{array}$ \\
\hline
\end{tabular}

